\title{
Pollution Prevention Opportunity Assessments of U.S. Army Corps of Engineers Civil Works Facilities
}

The Pollution Prevention Opportunity Assessments (PPOA) summarized here were conducted at the following representative U.S. Army Corps of Engineers (USACE) Civil Works facilities: Pittsburgh Engineering Warehouse and Repair Station (PEWARS) and Emsworth Locks and Dams in Pittsburgh, PA; Garrison Dam Hydroelectric Powerplant in Riverdale, ND; and John H. Kerr Dam and Reservoir in Boydton, VA. The PPOAs were conducted under the U.S. Environmental Protection Agency (EPA) Waste Reduction Evaluations At Federal Sites (WREAFS) Program and were funded by the Department of Defense Strategic Environmental Research and Development Program (SERDP).

Although the facilities studied were efficiently designed and employees have established numerous on-site procedures resulting in the reduction of waste generation, opportunities were identified for further action. The PPOA reports identify and discuss the economic and technical feasibility of potential source reduction and recycling opportunities at the facilities studied. The alternatives presented in the reports have application to similar Federal, non-Federal and private sector facilities.

This Project Summary was developed by EPA's National Risk Management Research Laboratory, Cincinnati, $\mathrm{OH}$, to announce key findings of the research project that is fully documented in three separate reports (see Project Report ordering information at back).

\section{Introduction}

This project summary describes three Pollution Prevention Opportunity Assessments conducted at U.S. Army Corps of Engineers Civil Works facilities under the Waste Reduction Evaluations At Federal Sites (WREAFS) Program. The purposes of the WREAFS Program are to identify new technologies and techniques for re ducing wastes from industrial processes at Federal sites, and to enhance the implementation of pollution prevention through technology transfer. New techniques and technologies for reducing waste generation are identified through pollution prevention opportunity assessments (PPOA) and may be further evaluated through joint research, development, and demonstration projects.

The assessments were conducted using the procedures outlined in EPA's Facility Pollution Prevention Guide (EPAV60/ R-92/088). The assessments had two major phases. The first phase quantified waste generation and management practices. The second phase identified and evaluated the feasibility of opportunities and techniques to eliminate, reduce, or recycle wastes.

The facilities studied in the PPOAs were: a navigation lock and dam; a warehouse and a maintenance and repair facility; a hydroelectric power plant; and a flood control dam and reservoir with associated public recreation areas. Other Federal agencies, such as the Bureau of Reclamation and the Tennessee Valley Authority have similar functions and facilities, as do states and the private sector. Thus, 
the results of the PPOAs described in the three full reports have applicability to a broad audience.

\section{Results and Discussion}

\section{Garrison Dam Hydroelectric Power Plant}

The Garrison Dam Hydroelectric Power Plant (GDHP) is located on the Missouri River 55 miles northwest of Bismarck, ND. For the most part the GDHP can serve as a model for a well-run, clean industrial facility, but there are two areas in which the GDHP can potentially reduce waste generation: (1) wicket gate lubrication; and (2) antifreeze and bubbler system operations. In addition, there are several less significant areas of potential improvement, such as oil sampling, parts cleaning, and recycling.

\section{Wicket Gate Lubrication}

The GDHP has five turbines, each located in a penstock and powering a generator. In the normal operation of a turbine, the wicket gates, which are inside the penstock directly above the turbines, control water flow passing from the penstock to the turbine. The bronze-coated wicket gate bearings, on which the wicket gates pivot, must be continuously lubricated.

The GDHP uses approximately 3,200 $\mathrm{lb} / \mathrm{yr}$ of a grease called Multifak EP2 to lubricate its wicket gate bearings. Essentially all of this grease escapes into the water flowing past the wicket gates.

Synthetic bearing systems have been installed in powerplant wicket gate bearings, as well as turbine main bearings and other bearings in turbine/wicket gate system. One system studied uses a bronzed bearing with a coating of a material called Thordon, which functions as a lubricantimpregnated spongelike matrix. Thordon systems have been used since the early 1970s, and appear to have an excellent reliability record. Most of the installations have been in Canadian facilities; however, similar systems have also been installed in one of the wicket gate systems at Tim's Ford Hydroelectric Powerplant, a Tennessee Valley Authority (TVA) facility.

A second system, the Lubron system, manufactured by Lubron Bearing Systems, uses a teflon base in a bronze substrate. The Teflon has lubrication in its matrix, and additional lubricant can be deposited in machined recesses in the bearings. Lubron is being used at the Tim's Ford
TVA plant in the shift ring for the wicket gate arms. The Lubron system was installed at the same time as the Thordon bearings, and has likewise performed without problems.

A general comparison of the bronze greased lubrication bearing system and the non-grease lubricated systems is included in the report.

\section{Chemical Antifreeze Use}

Ice formation on the spillway tainter gates prevents their proper working in case of an emergency discharge, and might damage the gates or cause them to fail. To keep ice formation from reaching the gates, the GDHP spillway was built with an underwater bubbler system. To supplement the bubbler system and clear the bubbler lines of ice, the GDHP employs chemical antifreeze treatment in the bubbler lines. Vaporized Frosto (mostly methanol) is injected into the compressed air bubbler lines running near the tainter gates.

Table 1 contains a summary of the possible alternative methods of reducing pollution from tainter gate deicing.

Table 2 contains a summary of the most significant waste streams generated by

Table 1. Options to Reduce Methanol Use at the Tainter Gates

Option to

Reduce

Methanol

Requirements for

Estimated

Use Introducing Option Costs

Advantages

Dredge lake bottom: stabilize lake banks; overhaul bubbler system

Operational readiness evaluation

Intermal evaluation by the USACE

\section{Physical ice} reduction options (heater system, water mixer)

Alternate chemical use

Pulse rate reduction
Evaluation of the tainter gates preceded by installation of system

Assessment of applicability in current system; might require extensive equipment modifications

Determine lowest reasonable level of chemical injection; make minor equipment modifications
$\$ 1.5$ million

The repair would allow bubbler to operate effectively; would reduce erosion of banks ensuring future operation of bubbler

No additional equipment or chemicals required; only procedural changes direct costs if a USACE research group performed the evaluation

Equipment cost is about $\$ 20,000$ per gate; electricity costs are hard to predict, but costs would likely be around $\$ 4,000$ per gate

Equipment modification costs are not predictable-they could be minimal or run into many thousands of dollars; chemical costs would be similar to current chemical costs

Total costs would likely not exceed \$1,000 per unit; some units allow pulse reduction by simply changing their settings
Once installed, units would generate little pollution and allow less antifreeze to be consumed duced to the environment would be reduced

Simple, low cost pollution prevention measure
Toxicity of chemicals intro-
Evaluation may take time; USACE may feel operational readiness can not be compromised

Data on systems only from 1991 forward, so reliability is not confirmed; increased electricity consumption

Total chemical consumption might not markedly change; feasibility of modifying equipment must be assessed

If chemicals are reduced too much ice might form at tainter gates 


\section{DISCLAIMER}

This report was prepared as an account of work sponsored by an agency of the United States Government. Neither the United States Government nor any agency thereof, nor any of their employees, make any warranty, express or implied, or assumes any legal liability or responsibility for the accuracy, completeness, or usefulness of any information, apparatus, product, or process disclosed, or represents that its use would not infringe privately owned rights. Reference herein to any specific commercial product, process, or service by trade name, trademark, manufacturer, or otherwise does not necessarily constitute or imply its endorsement, recommendation, or favoring by the United States Government or any agency thereof. The views and opinions of authors expressed herein do not necessarily state or reflect those of the United States Government or any agency thereof. 


\section{DISCLAIMER}

Portions of this document may be illegible in electronic image products. Images are produced from the best available original document. 
Table 2. Summary of Significant Waste Streams Generated by the GDHP and Recommended Options for the Waste Stream Reduction or Modification

\begin{tabular}{|c|c|c|c|}
\hline Waste(s) Generated & $\begin{array}{c}\text { Source of Waste } \\
\text { Generation }\end{array}$ & $\begin{array}{c}\text { Amount of Waste } \\
\text { Generation }\end{array}$ & Recommended Options \\
\hline Frosto (mostly methanol) & $\begin{array}{l}\text { Bubbler system } \\
\text { operation }\end{array}$ & $\begin{array}{l}\text { Approximately } \\
1,650 \text { gallyr }\end{array}$ & $\begin{array}{l}\text { 1. Repair bubbler system } \\
\text { 2. Add heating elements } \\
\text { 3. Use alternate antifreeze } \\
\text { 4. Lower antifreeze injection pulse rate to bubbler } \\
\text { 5. Reassess need for fully operational spillway year-round }\end{array}$ \\
\hline Multifak EP2 & $\begin{array}{l}\text { Wicket gate } \\
\text { lubrication }\end{array}$ & $\begin{array}{l}\text { Approximately } \\
1,500 \text { gal/yr }\end{array}$ & $\begin{array}{l}\text { Install non-grease lubricated bearings in } \\
\text { wicket gate system }\end{array}$ \\
\hline $\begin{array}{l}\text { Lubricant, transformer, and } \\
O C B \text { oil }\end{array}$ & Oil testing & $\begin{array}{l}\text { Approximately } \\
30 \text { gal/yr }\end{array}$ & $\begin{array}{l}\text { 1. Reduce sampling volumes to lowest levels possible } \\
\text { 2. Reduce sampling frequency to lowest reasonable levels }\end{array}$ \\
\hline $\begin{array}{l}\text { Lubricant, transformer, and } \\
O C B \text { oil; filters; oil sludge }\end{array}$ & Oil transfer and recycling & $\begin{array}{l}\text { Less than } 20 \text { gallyr } \\
\text { oil; less than } 100 \mathrm{lb} \\
\text { of filter waste; less than } \\
30 \text { gallyr sludge }\end{array}$ & $\begin{array}{l}\text { 1. Use caution during transfers } \\
\text { 2. Reduce recycling frequencies if feasible }\end{array}$ \\
\hline Mineral Spirits & Parts washing & $\begin{array}{l}\text { Approximately } \\
55 \text { gallyr }\end{array}$ & $\begin{array}{l}\text { 1. Use ultrasonic cleaners instead of solvent bath } \\
\text { 2. Locate acceptable alternate solvent with preferable } \\
\text { environmental characteristics }\end{array}$ \\
\hline
\end{tabular}

the GDHP, and options recommended for those streams.

\section{Pittsburgh Engineer Warehouse and Repair Station (PEWARS) and Emsworth Locks and Dams}

The Pittsburgh Engineer Warehouse and Repair Station (PEWARS) is located on Neville Island between the main and back channels of the Ohio River near the town of Emsworth, PA. Operations performed at the two facilities are related, in that PEWARS performs painting, depainting, storage, and routine and major maintenance operations for all flood control and navigation projects in the USACE Pittsburgh District, including Emsworth; however, normal operations are quite different at the two facilities.

The Emsworth Locks and Dams System is located on the Ohio River, 6.2 miles downstream of Pittsburgh, PA. The main portion of the project consisting of two locks and a gated dam, located on the main channel. The second portion, which consists of a single gated dam, is located on the back channel of the river. The dams are created to maintain a channel depth that will accommodate large vessels, such as commercial barges. The locks enable vessels to be raised or lowered to the water levels created by the dams.

Both Emsworth Locks and Dams and PEWARS have areas of operations that could benefit from the following pollution prevention initiatives.

1. Installation of non-grease lubricated bearings, chains, gears, and other components in the lock and dam system where possible. A major task involved during routine maintenance activities conducted on the lock-operating machinery is ensuring that a proper amount of lubricant is present on all bearings and other parts requiring lubrication. Synthetic systems have been used in water containing relatively high concentrations of undissolved solids, as might be found in lock and dam systems; however, there is no proven history of the application of synthetic materials in lock and dam systems. Its use in this situation could be studied and demonstrated.

2. Replacement of the current centralized hydraulic system with localized units incorporating accessible oil flow lines. Hydraulic pressure is used in the daily operation of the Emsworth Locks and Dams to open and close the lock gates and butterfly valves in the lock system. If a break occurs in one of the hydraulic lines, a significant spill could occur in a short period of time. It would be environ- mentally preferable to install a system with localized hydraulic oil units, like the system currently used at Emsworth to operate the tow haulage and retriever system.

3. Substitution of the current depainting method with a lowerwaste generating alternative. PEWARS utilizes a product called Black Beauty (made up of bituminous coal) applied with a Chemco sandblaster for paint removal. Once a gate is depainted, the blast material is tested for lead content. If the lead content is greater than $5 \mathrm{ppm}$, the waste must be disposed of as hazardous waste. The possible substitutes for the current depainting method at PEWARS are: (1) open abrasive blast cleaning with recyclable abrasives; (2) high pressure water jetting with abrasives; and (3) ultra-high pressure water jetting with abrasives. Table 3 contains a direct comparison of these three methods.

4. Substitution of the current paint and application method with a lower VOC-emitting system. PEWARS has already undertaken major steps to reduce pollution generated by painting. The use of an airless spray system with epoxy paint complies with requirements for VOC levels in paints, which must 
Table 3. Comparison of Recommended Alternative Paint Removal Methods

\begin{tabular}{|c|c|c|c|c|c|c|}
\hline $\begin{array}{l}\text { Method } \\
\text { Number }\end{array}$ & $\begin{array}{l}\text { Method } \\
\text { Name }\end{array}$ & $\begin{array}{l}\text { Equipment } \\
\text { INvestment }\end{array}$ & $\begin{array}{l}\text { Removal } \\
\text { Efficiency }\end{array}$ & $\begin{array}{l}\text { Production } \\
\text { Speed }\end{array}$ & $\begin{array}{l}\text { Environmental } \\
\text { Advantages }\end{array}$ & $\begin{array}{l}\text { Environmental } \\
\text { Disadvantages }\end{array}$ \\
\hline 2 & $\begin{array}{l}\text { Open abrasive blast } \\
\text { cleaning with recycl- } \\
\text { able abrasive }\end{array}$ & $\begin{array}{l}\text { Very } \\
\text { expensive }\end{array}$ & $\begin{array}{l}\text { Excellent in all } \\
\text { areas }\end{array}$ & Very high & $\begin{array}{l}\text { Recycling of abrasive } \\
\text { results in lowest vol- } \\
\text { ume of waste gener- } \\
\text { ation of tested meth- } \\
\text { ods }\end{array}$ & $\begin{array}{l}\text { Waste may be hazardous } \\
\text { due to potential for in- } \\
\text { creased lead concen- } \\
\text { trations }\end{array}$ \\
\hline 6 & $\begin{array}{l}\text { High pressure water } \\
\text { jetting with abrasive } \\
\text { injection }\end{array}$ & Expensive & $\begin{array}{l}\text { Good to } \\
\text { excellent in } \\
\text { all areas }\end{array}$ & $\begin{array}{l}\text { Moderate } \\
\text { to high }\end{array}$ & $\begin{array}{l}\text { Much less debris } \\
\text { than current method }\end{array}$ & $\begin{array}{l}\text { More debris than method } \\
2 ; \text { waste may be hazardous } \\
\text { due to potential for in- } \\
\text { creased lead concentrations }\end{array}$ \\
\hline 8 & $\begin{array}{l}\text { Ultra-high pressure } \\
\text { water jetting with } \\
\text { abrasive injection }\end{array}$ & $\begin{array}{l}\text { Very } \\
\text { expensive }\end{array}$ & $\begin{array}{l}\text { Good to } \\
\text { excellent in } \\
\text { all areas }\end{array}$ & High & $\begin{array}{l}\text { Much less debris } \\
\text { than current method }\end{array}$ & $\begin{array}{l}\text { More debris than method } \\
\text { 2; waste may be hazardous } \\
\text { due to potential for increased } \\
\text { lead concentrations }\end{array}$ \\
\hline
\end{tabular}

contain less than $2.8 \mathrm{lb} / \mathrm{gal}$. This system is also easily applied and has shown reasonable durability. However, there are alternative systems being developed which may prove to be reliable and reduce waste generation. These alternatives are shown in Table 4. Any of these three methods would produce significantly less solid waste than the current operations at PEWARS.

5. Further implementing the centralization of and tracking system for the inventory control process. This would help prevent purchasing duplicate materials, and therefore reduce shelf-life losses.

Of the five initiatives given above, Numbers 1 and 2 are applicable to any lock and dam site. Numbers 3,4 and 5 would apply to any facility that performs major maintenance or storage. Number 3 appears to be an excellent candidate for a demonstration project. Initiative 4 could also prove beneficial if powder or $100 \%$ solid coatings progress to the point where they are suitable for conditions such as those found at PEWARS and Emsworth Locks and Dams.

Table 5 provides a list of waste streams generated at Emsworth and PEWARS, and options recommended for those waste streams.

\section{John H. Kerr Dam and Reservoir}

The John H. Kerr Dam and Reservoir is located on the Roanoke River 55 miles north of Raleigh, NC and 100 miles southwest of Richmond, VA. The project was authorized by the Flood Control Act of 1944 , and was constructed for flood control and aquatic recreation needs. Additional purposes of the project include domestic water supply, water supply for hydroelectric power generation, water quality control, wildlife management, and navigation.

The facilities discussed in the full report are: (1) North Bend Park maintenance facility, spray irrigation water treatment system, marina, and campground, all operated by USACE; (2) Longwood Park, operated by USACE; (3) the pump station at Island Creek Dam, operated by USACE; (4) Satterwhite Point State Park maintenance facility and wastewater treatment system, operated under lease by the State of North Carolina Department of Parks and Recreation; and (5) the Clarksville Marina, a privately owned concession under lease.

There has been substantial cooperation between these Federal, state, local, and private organizations. However, several specific areas were identified which could benefit from pollution prevention efforts. These areas are summarized in Table 6.

\section{Conclusion}

For the most part, the majority of environmental effects from USACE Civil Works facilities occur during construction. Less pollution is generated as a result of the operation, maintenance, replacement or repair of these facilities; however, several areas can be targeted for pollution reduction. At Garrison Dam Hydroelectric Powerplant, the six areas identified for the greatest potential reduction in waste generations were wicket gate lubrication, tainter gate maintenance, oil sampling and recycling, parts washing, consumer product recycling, and inventory control. The greatest potential for pollution reduction at PEWARS and Emsworth Locks and Dams were lubrication and the hydraulic system used to transport the oils; painting and depainting, and inventory control practices. At John H. Kerr Dam and Reservoir, the areas of greatest pollution prevention potential were expanding the use of recycled plastic timbers instead of creosoted railroad ties, oily rag generation, antifreeze for toilets and piping, parts washing and degreasing, solid waste separation and recycling, and inventory control.

The full reports were submitted in fulfillment of Contract No. 68-D2-0181, Work Assignment No. 1-011 by TRC Environmental Corporation under the sponsorship of the U.S. Environmental Protection Agency. 


\begin{tabular}{|c|c|c|c|c|c|c|}
\hline Paint & Life Expectancy & $\operatorname{Cos} t\left(s / t^{2}\right)$ & $\begin{array}{l}\text { Preferred } \\
\text { Application } \\
\text { Method }\end{array}$ & voc Content & Advantages & Disadvantages \\
\hline Vinyl resins & $20-40 y r$ & $\$ 1.00$ & brush, roll, spray & $70-75 \%$ by weight & $\begin{array}{l}\text { Short cure, easy to apply, excell- } \\
\text { ent durability }\end{array}$ & $\begin{array}{l}\text { Large source of VOC emiss- } \\
\text { ions, significant surface } \\
\text { preparation }\end{array}$ \\
\hline 2-part epoxy & $15-20 y r$ & $\$ 1.60$ & spray & $<2.8 \mathrm{lb} / \mathrm{gal}$ & Easy to apply, good durability & $\begin{array}{l}\text { Long cure, temperature sensitive, } \\
\text { abrasion sensitive, chalking in } \\
\text { sunlight }\end{array}$ \\
\hline Coal tar epoxy & $15-20 y r$ & $N A^{*}$ & spray & $20.30 \%$ by weight & $\begin{array}{l}\text { Excellent durability, less significant } \\
\text { surface preparation }\end{array}$ & Toxicity \\
\hline Air-cured urethanes & $<5 y r$ & $\$ 2.00-\$ 3.00$ & $N A^{*}$ & $<2.8 \mathrm{lb} / \mathrm{gal}$ & $\begin{array}{l}\text { Low VOC emissions, not } \\
\text { sensitive to sunlight }\end{array}$ & $\begin{array}{l}\text { Current life expect- } \\
\text { ancy not high }\end{array}$ \\
\hline $\begin{array}{l}\text { Moisture-cured } \\
\text { urethanes }\end{array}$ & $\begin{array}{l}\text { Currently under } \\
\text { testing by USACE }\end{array}$ & $N A^{*}$ & $N A^{*}$ & $<.8 \mathrm{lb} / \mathrm{gal}$ & $\begin{array}{l}\text { Short cure, less significant surface } \\
\text { preparation }\end{array}$ & $\begin{array}{l}\text { Moisture sensitive during } \\
\text { application }\end{array}$ \\
\hline $100 \%$ solids & $\begin{array}{l}\text { Currently under } \\
\text { testing by USACE }\end{array}$ & $N A^{*}$ & spray & none & No VOC emissions & $\begin{array}{l}\text { Difficult to apply, not } \\
\text { water resistant }\end{array}$ \\
\hline Powder coatings & $<5 y r$ & $N A^{*}$ & spray & none & No VOC emissions & $\begin{array}{l}\text { Very sensitive to abrasion, poor } \\
\text { durability }\end{array}$ \\
\hline
\end{tabular}

- NA - not available, paint and application method is currently under development.

Table 5. Summany of Significant Waste Streams Generated by Emsworth and PEWARS and Recommended Options for Waste Stream Reduction or Modification

\begin{tabular}{|c|c|c|c|c|c|c|}
\hline Wastes Generated & $\begin{array}{l}\text { Source of Waste } \\
\text { Generation }\end{array}$ & $\begin{array}{l}\text { Environmental } \\
\text { Disadvantages }\end{array}$ & $\begin{array}{l}\text { Recommended } \\
\text { Options }\end{array}$ & Advantages & Disadvantages & Recommendations \\
\hline \multicolumn{7}{|l|}{ Emsworth } \\
\hline $\begin{array}{l}\text { Lubriplate, Never } \\
\text { Seez } \\
\text { lon and engine oil }\end{array}$ & $\begin{array}{l}\text { Lubrication of lock and } \\
\text { dam equipment }\end{array}$ & $\begin{array}{l}\text { Lubricants eventually } \\
\text { escape into environ- } \\
\text { ment }\end{array}$ & $\begin{array}{l}\text { Installation of non-grease } \\
\text { lubricated systems }\end{array}$ & $\begin{array}{l}\text { No grease allowed to es- } \\
\text { cape into environment }\end{array}$ & $\begin{array}{l}\text { Cost can be very high } \\
\text { due to loss of operation }\end{array}$ & $\begin{array}{l}\text { Installation should only be considered } \\
\text { during necessary overhaul }\end{array}$ \\
\hline Hydraulic oll & $\begin{array}{l}\text { Main hydraulle system } \\
\text { leaks and line breaks }\end{array}$ & $\begin{array}{l}\text { Oll escapes into } \\
\text { onvironment }\end{array}$ & $\begin{array}{l}\text { Installation of localized } \\
\text { oll-sending units with } \\
\text { accessible lines }\end{array}$ & $\begin{array}{l}\text { Reduced chance of oil } \\
\text { leakage to environment }\end{array}$ & Cost would be high & $\begin{array}{l}\text { Installation should only be considered } \\
\text { during necessary overhaul }\end{array}$ \\
\hline \multicolumn{7}{|l|}{ PEWARS } \\
\hline Depainting wastes & $\begin{array}{l}\text { Paint removal from lock } \\
\text { gates with expendable } \\
\text { abrasives }\end{array}$ & $\begin{array}{l}\text { High waste volumes } \\
\text { generated using } \\
\text { current process }\end{array}$ & $\begin{array}{l}\text { Altermative, lower waste } \\
\text { volume methods }\end{array}$ & $\begin{array}{l}\text { Drastic reduction in solid } \\
\text { waste volume generation }\end{array}$ & $\begin{array}{l}\text { Disposal costs may go up, } \\
\text { equipment investment } \\
\text { would be costly }\end{array}$ & $\begin{array}{l}\text { Alternative methods would be excellent } \\
\text { demonstration projects }\end{array}$ \\
\hline $\begin{array}{l}\text { Painting waste } \\
\text { and VOCs }\end{array}$ & $\begin{array}{l}\text { Painting of lock gates } \\
\text { using epoxy paint and } \\
\text { spray system }\end{array}$ & $\begin{array}{l}\text { VOCs are increasingly } \\
\text { regulated, spray system } \\
\text { has fairly large overspray }\end{array}$ & $\begin{array}{l}\text { Powder or 100-percent } \\
\text { solids paints and HVLP } \\
\text { system }\end{array}$ & $\begin{array}{l}\text { No VOC and low paint } \\
\text { waste generation }\end{array}$ & $\begin{array}{l}\text { Paint and application } \\
\text { system still under } \\
\text { development }\end{array}$ & $\begin{array}{l}\text { Altemative method would be excellent } \\
\text { demonstration project }\end{array}$ \\
\hline $\begin{array}{l}\text { Various chemicals } \\
\text { and other materials }\end{array}$ & Excess purchases & $\begin{array}{l}\text { Materials that could be } \\
\text { used at other District } \\
\text { facilities could expire }\end{array}$ & $\begin{array}{l}\text { Further centralizing pur- } \\
\text { chasing; accessible, up- } \\
\text { dated inventory of materials }\end{array}$ & Reduced waste & $\begin{array}{l}\text { Purchasing system must } \\
\text { be updated and personnel } \\
\text { must make effort to follow } \\
\text { system }\end{array}$ & $\begin{array}{l}\text { Continue centralization and inventory } \\
\text { control }\end{array}$ \\
\hline
\end{tabular}


Table 6. Summary of Pollution Prevention Recommendations for John H. Kerr Dam and Reservoir Areas

\begin{tabular}{|c|c|c|c|c|}
\hline $\begin{array}{c}\text { Site for } \\
\text { Implementation }\end{array}$ & $\begin{array}{c}\text { Activity } \\
\text { Description }\end{array}$ & Current Practice & $\begin{array}{c}\text { Recommended } \\
\text { Alternative Practice }\end{array}$ & $\begin{array}{l}\text { Benefits of } \\
\text { Alternative }\end{array}$ \\
\hline All locations & Railroad tie replacement & $\begin{array}{l}\text { Wood, creosote, and recycled } \\
\text { plastic tie replacements }\end{array}$ & $\begin{array}{l}\text { Use recycled plastic ties as } \\
\text { much as possible }\end{array}$ & $\begin{array}{l}\text { Reduces use of virgin } \\
\text { materials }\end{array}$ \\
\hline $\begin{array}{l}\text { North Bend State Park- } \\
\text { Maintenance Facilities }\end{array}$ & $\begin{array}{l}\text { Oily rag generation from } \\
\text { car oil changes }\end{array}$ & Disposal in 55-gal drums & $\begin{array}{l}\text { Wringer system to recover oil } \\
\text { and allow reuse of rags }\end{array}$ & $\begin{array}{l}\text { Reduces amount of } \\
\text { oil and rags consumed }\end{array}$ \\
\hline $\begin{array}{l}\text { North Bend State Park- } \\
\text { Maintenance Facilities, } \\
\text { Satterwhite Point State Park }\end{array}$ & $\begin{array}{l}\text { Antifreeze for toilets and } \\
\text { piping }\end{array}$ & $\begin{array}{l}\text { Ethylene glycol used as } \\
\text { an antifreeze }\end{array}$ & $\begin{array}{l}\text { Use of propylene glycol instead } \\
\text { of ethylene glycol }\end{array}$ & Much lower toxicity \\
\hline $\begin{array}{l}\text { North Bend State Park- } \\
\text { Maintenance Facilities, } \\
\text { Clarksville Marina }\end{array}$ & $\begin{array}{l}\text { Parts washing and } \\
\text { degreasing }\end{array}$ & $\begin{array}{l}\text { Mineral spirits used in } \\
\text { parts washer }\end{array}$ & $\begin{array}{l}\text { Alternative solvent, such as } \\
\text { various DuPont@ solvents }\end{array}$ & Reduced VOC emissions \\
\hline $\begin{array}{l}\text { North Bend State Park, } \\
\text { Satterwhite Point State Park }\end{array}$ & Solid waste separation & $\begin{array}{l}\text { Many recyclable materials } \\
\text { are disposed of as solid } \\
\text { waste }\end{array}$ & $\begin{array}{l}\text { Encourage recycling, allow civic } \\
\text { groups to collect recyclables, } \\
\text { provide bins }\end{array}$ & $\begin{array}{l}\text { Reduced solid waste } \\
\text { generation }\end{array}$ \\
\hline $\begin{array}{l}\text { Island Creek Dam and } \\
\text { Pump Station }\end{array}$ & Inventory control & $\begin{array}{l}\text { Materials are not always } \\
\text { accounted for and can be } \\
\text { allowed to expire }\end{array}$ & $\begin{array}{l}\text { Ensure adequate recordkeeping, } \\
\text { allow unneeded chemicals to be } \\
\text { distributed }\end{array}$ & $\begin{array}{l}\text { Reduced solid and } \\
\text { hazardous waste } \\
\text { generation }\end{array}$ \\
\hline $\begin{array}{l}\text { Clarksville Marina and } \\
\text { other marinas }\end{array}$ & Human waste disposal & $\begin{array}{l}\text { Boaters must haul wastes } \\
\text { up hill and pay fee }\end{array}$ & $\begin{array}{l}\text { Put sewer hookups near boats, } \\
\text { recoup fee in a less } \\
\text { direct method }\end{array}$ & $\begin{array}{l}\text { Reduce unsanitary } \\
\text { waste disposal }\end{array}$ \\
\hline
\end{tabular}

